Dept. of Biochemistry, Faculty of Veterinary Medicine,

Istanbul University, Avcilar, 34310 Istanbul, Turkey.

\title{
CHANGES IN SOME ENZYME ACTIVITIES DURING LATE PREGNANCY, PARTURITION AND EARLY LACTATION IN THOROUGHBRED ARABIAN RACE MARES
}

(With 2 Tables)

By

\section{ATILA ATES; AYSEL ÖZPINAR* and AYSEN ALTINER*}

* University of California, Davis Western Institute for Food Safety and Security, School of Veterinary Medicine, 279 Cousteau Place, Ste 100 Davis, California 95616-8734, USA

(Received at 12/5/2010)

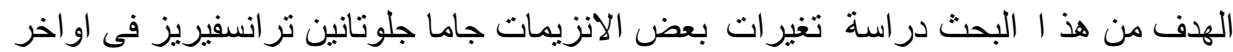

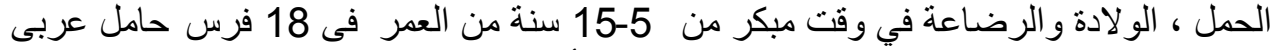

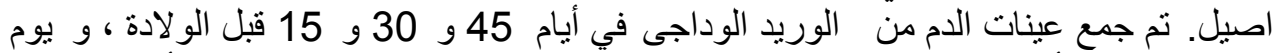

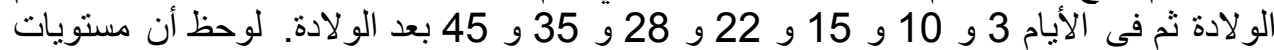

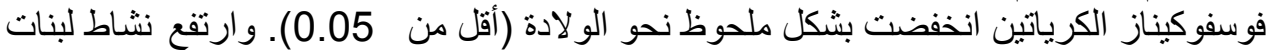

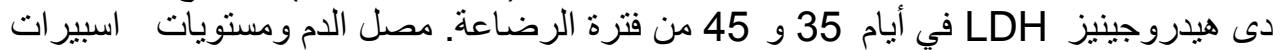
أمينوتر انسفيريز AST أظهرت زياديز

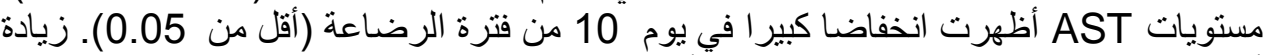

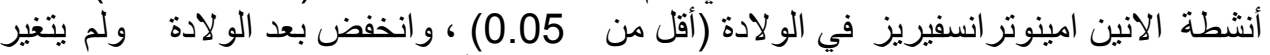

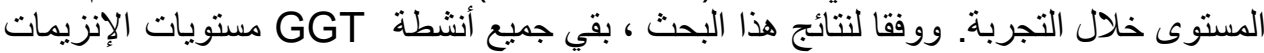

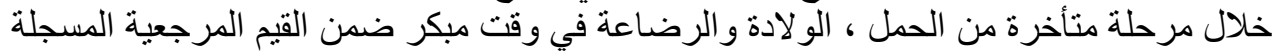

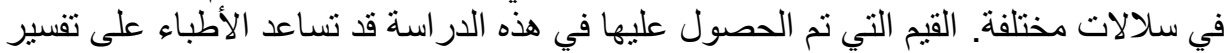

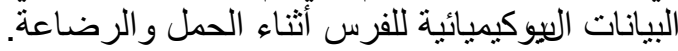
كلمات الإفتتاح : أفراس ، أنزيم ، أواخر الحمل ، العل ، الولادة ، الرضاعة الربكرة

\section{SUMMARY}

The aim of this study was to investigate the changes in CPK, LDH, AST, ALT, ALP and GGT activities during late pregnancy, parturition and early lactation in 5-15 years old 18 pregnant thoroughbred Arabian race mare. Blood samples were collected from jugular vein on days 45,30 and 15 before parturition, at parturition and on days 3, 10, 15, 22, 28, 35 and 45 after parturition. Serum CPK levels significantly decreased towards parturition $(\mathrm{p}<0.05)$. Serum LDH activities rose on days 35 and 45 of lactation period. Serum AST and ALT levels showed significant increases on day 30 before parturition $(\mathrm{p}<0.05)$. Serum ALT levels showed a 
significant decrease on day 10 of lactation period $(\mathrm{p}<0.05)$. Serum ALP activities increased at parturition $(\mathrm{p}<0.05)$ and decreased after parturition. Serum GGT levels did not change during the study period. According to the present research results, activities of all enzymes during late pregnancy, parturition and early lactation remained within reference values recorded in different breeds or species. The values obtained in this study may assist clinicians to interpret biochemical data of mare in pregnancy and lactation.

Key words: Mare, enzyme, late pregnancy, parturition, early lactation.

\section{INTRODUCTION}

The intensity of metabolism and the metabolic parameters in the blood of a mare are widely influenced by pregnancy and lactation (Milincovic-Tur et al., 2005). Homeostatic mechanisms function to keep substances in blood at relatively constant levels; some changes in clinical biochemistry analytes are likely to occur (Harvey et al., 2005). Increases in plasma enzyme activities are usually related to leakage of enzymes from damaged cells. The amount of increase for a particular enzyme depends on factors such as the activity of enzyme in the cells, its rate of leakage from the cells and the rate of its clearance from the plasma (Lumej et al., 1988).

The use of plasma enzyme activities as a diagnostic aid is a well established procedure in veterinary medicine (Lumej et al., 1988). Liver disease is a relatively common cause of illness in the adult horse and is most commonly recognized by identification of icterus, weight loss, and behavioral changes (Johns et al., 2007). A large increase in the activity of the specific and non-specific [lactate dehydrogenase (LDH), aspartate aminotransferase (AST)] hepatocellular enzymes with a parallel moderate increase in enzymes existed mostly in the biliary tract [gamma-glutamyl transferase $(\gamma-\mathrm{GT})$, alkaline phosphatase (ALP)] are generally considered to be suggestive of a primary hepatocellular disease, whereas a severe increase in the enzymes of the biliary tract with no change or slight to moderate increase in the hepatocellular enzymes is suggestive of a disease mainly inducing cholestasis, thus of a post-hepatic disease (Amory et al., 2005).

The activity of aminotransferases in blood is very important because they act as a catalyst in connection with the metabolism of amino acids and carbohydrates. Changes in their activity in the blood can be a consequence of their increased activity in the cells, or cell structure damage (Milincovic-Tur et al., 2005). Activity of AST in horses is much higher than in other animals (Milincovic-Tur et al., 2005), but not "liver specific", but may be of use diagnostically to measure the level of liver necrosis if all 
tissues other than liver are known to be free of pathology (Kaneko and Cornelius, 1971). Alanine aminotransferase (ALT) activity in horses is not specific for the liver, in order to have a diagnostic significance. ALT activity in the blood plasma is influenced by age and muscle activity (Milincovic-Tur et al., 2005).

In mammalian cells, ALP is a widely distributed enzyme. It is often associated with cell membranes, but its exact physiologic function is unknown. However, ALP activity is a very useful serum biochemical indicator of liver disease, especially cholestatic disease. However, increases in the activity of ALP in serum and other body fluids may reflect physiologic or pathologic changes beyond those of hepatic origin. For example, nonhepatic increases in serum ALP activity are found in young animals, in pregnant and lactating females, and in association with high fat diets. Bone disease, endocrine disease, neoplasia, and other disorders can result in increased ALP activity (Fernandez and Kidney, 2007).

In the plasma, $\gamma$-GT is significant as a sign of hepatobiliary system diseases connected with cholestasis and is used in diagnosing liver disease. In the liver of the horse, $\gamma$-GT activity is relatively high (Milincovic-Tur et al., 2005; Stojevic et al., 2005). In the healthy horse, the effect of exercise on creatine phosphokinase (CPK) activities depends on the fitness of the animal, the intensity and duration of the exercise as well as the environment (Harris et al., 1998).

The aim of this study was to investigate the changes in CPK, LDH, AST, ALT, ALP and $\gamma$-GT activities during late pregnancy, parturition and early lactation in thoroughbred Arabian race mares.

\section{MATERIALS and METHODS}

Eighteen pregnant thoroughbred Arabian race mares, 5-15 years old, from Izmit Pension Stud of Turkey Jockey Club were used in the study. The mares were fed $2.4 \mathrm{~kg} /$ day concentrate (Table 1) and hay ad libitum. They were housed in pasture by day and in shed at night. Blood samples were collected from jugular vein by vacutainer tubes on $45^{\text {th }}, 30^{\text {th }}$ and $15^{\text {th }}$ days before parturition, at parturition and on $3^{\text {rd }}, 10^{\text {th }}, 15^{\text {th }}, 22^{\text {nd }}$, $28^{\text {th }}, 35^{\text {th }}$ and $45^{\text {th }}$ days after parturition. Samples were allowed to clot at room temperature and sera were separated by centrifugation at $3000 \mathrm{rpm}$ for $10 \mathrm{~min}$. and stored at $-20^{\circ} \mathrm{C}$ until analysed. Frozen samples were held in storage for no more than one week, when biochemical analyses were carried. All mares appeared clinically healthy, and they were handled with care to minimize any possible effects of stress. Serum CPK, LDH, AST, ALT, ALP and $\gamma$-GT activities were determined in a Cobas Bio autoanalyser (Roche, Nuttley, NY) by commercial kits (Randox 
Laboratories ltd., Co. Antrim, United Kingdom, BT29 4QY). The quality control and calibration of equipment were performed with Randox assayed control serum and precision control serum.

Statistical analyses were performed using a statistical software package program (SPSS, version 10.0). Using a general linear model, an ANOVA (Duncan test) was used to compare changes in serum enzyme activities between blood sampling days. Differences were considered significant at $p<0.05$. Using this linear model, contrasts were performed for successive days from -45 days before parturition to 45 days after parturition. Data are expressed as mean \pm standard error.

Table 1: Content and chemical composition of diet

\begin{tabular}{|l|c|}
\hline \multicolumn{1}{|c|}{ Ingredients } & $(\mathrm{g} / \mathrm{kg})$ \\
\hline Oat & 350 \\
Corn & 340 \\
Vegetable oil & 50 \\
Lucerne meal & 202 \\
Wheat bran & 40 \\
Salt & 8 \\
Vitamin-mineral premix & 10 \\
\hline \multicolumn{1}{|c|}{ Calculated composition / kg } & \\
\hline Digestible energy (MJ) & 12.7 \\
Digestible crude protein (g) & 76 \\
Calcium (g) & 5 \\
Phosphorus (g) & 3.5 \\
Natrium (g) & 4 \\
Chlorine (g) & 5.3 \\
Vitamin A (IU) & 23.000 \\
Vitamin E (mg) & 35 \\
\hline
\end{tabular}

\section{RESULTS}

Serum CPK, LDH, AST, ALT, ALP and $\gamma$-GT activities of mares in late pregnancy, parturition and lactation period are shown in Table 2.

Serum CPK levels significantly decreased nearby parturition $(\mathrm{p}<0.05)$ but increased at parturition, and remained constant during lactation. Serum LDH activities insignificantly decreased till parturition. They rose on $35^{\text {th }}$ and $45^{\text {th }}$ days of lactation period $(\mathrm{p}<0.05)$. Serum AST levels generally remained constant during the study period but showed a significant increase 30 days before parturition $(\mathrm{p}<0.05)$ and then decreased. Serum ALT levels showed a significant increase 30 days before parturition and a significant decrease on the $10^{\text {th }}$ day of lactation period $(\mathrm{p}<0.05)$. Serum ALP activities significantly rose at parturition $(\mathrm{p}<0.05)$ and then decreased. Serum $\gamma$-GT activities showed constant levels during the study period. 
Table 2: Serum enzyme activities during late pregnancy, parturition and lactation in mares $(n=18)$

\begin{tabular}{|c|c|c|c|c|c|c|c|c|c|c|c|}
\hline $\begin{array}{l}\quad \text { Days } \\
\text { Enzymes } \\
(\mathrm{IU} / \mathrm{L})\end{array}$ & -45 & -30 & -15 & 0 & +3 & +10 & +15 & +22 & +28 & +35 & +45 \\
\hline $\begin{array}{l}\text { Creatine } \\
\text { phosphokinase } \\
\text { (CPK) }\end{array}$ & $171 \pm 20^{\mathrm{a}}$ & $117 \pm 13^{b}$ & $108 \pm 6^{\mathrm{b}}$ & $170 \pm 18^{\mathrm{a}}$ & $161 \pm 12^{\mathrm{a}}$ & $155 \pm 10^{\mathrm{a}}$ & $151 \pm 9^{\mathrm{a}}$ & $170 \pm 12^{\mathrm{a}}$ & $188 \pm 13^{\mathrm{a}}$ & $185 \pm 12^{\mathrm{a}}$ & $183 \pm 12^{\mathrm{a}}$ \\
\hline $\begin{array}{l}\text { Lactate } \\
\text { dehydrogenase } \\
\text { (LDH) }\end{array}$ & $453 \pm 25^{b}$ & $450 \pm 29^{\mathrm{b}}$ & $440 \pm 23^{b}$ & $486 \pm 40^{\mathrm{ab}}$ & $491 \pm 28^{\mathrm{ab}}$ & $509 \pm 35^{\text {ab }}$ & $495 \pm 30^{\mathrm{ab}}$ & $517 \pm 13^{\mathrm{ab}}$ & $496 \pm 29^{\mathrm{ab}}$ & $583 \pm 40^{\mathrm{a}}$ & $571 \pm 52^{a}$ \\
\hline $\begin{array}{l}\text { Aspartate } \\
\text { aminotransferase } \\
\text { (AST) }\end{array}$ & $203 \pm 11^{\mathrm{b}}$ & $282 \pm 29^{\mathrm{a}}$ & $212 \pm 15^{\mathrm{b}}$ & $215 \pm 14^{b}$ & $234 \pm 14^{\mathrm{ab}}$ & $223 \pm 11^{\mathrm{b}}$ & $235 \pm 16^{\mathrm{ab}}$ & $240 \pm 8^{\mathrm{ab}}$ & $228 \pm 12^{\mathrm{b}}$ & $237 \pm 12^{\text {ab }}$ & $227 \pm 12^{\mathrm{b}}$ \\
\hline $\begin{array}{l}\text { Alanine } \\
\text { aminotransferase } \\
\text { (ALT) }\end{array}$ & $3.66 \pm 0.289^{\mathrm{bc}}$ & $4.62 \pm 0.385^{\mathrm{a}}$ & $3.69 \pm 0.175^{\mathrm{abc}}$ & $4.14 \pm 0.261^{\mathrm{abc}}$ & $4.57 \pm 0.359^{9 \mathrm{ab}}$ & $3.46 \pm 0.247^{\circ}$ & $3.72 \pm 0.240^{\mathrm{abc}}$ & $4.07 \pm 0.245^{\mathrm{abc}}$ & $3.78 \pm 0.222^{\mathrm{abc}}$ & $3.80 \pm 0.200^{\mathrm{abc}}$ & $3.80 \pm 0.200^{\mathrm{abc}}$ \\
\hline $\begin{array}{l}\text { Alkaline } \\
\text { phosphatase } \\
\text { (ALP) }\end{array}$ & $238 \pm 18^{\mathrm{e}}$ & $264 \pm 12^{\text {cde }}$ & $259 \pm 29^{\text {de }}$ & $400 \pm 28^{\mathrm{a}}$ & $344 \pm 22^{\mathrm{b}}$ & $308 \pm 21^{\text {bcd }}$ & $316 \pm 18^{\text {bcd }}$ & $310 \pm 21^{\text {bcd }}$ & $310 \pm 21^{\text {bcd }}$ & $310 \pm 17^{\text {bcd }}$ & $326 \pm 18^{\mathrm{bc}}$ \\
\hline $\begin{array}{l}\text { Gamma } \\
\text { glutamyl } \\
\text { transferase } \\
(\gamma-\mathrm{GT})\end{array}$ & $12.8 \pm 1.59^{\mathrm{a}}$ & $15.4 \pm 1.56^{\mathrm{a}}$ & $14.9 \pm 1.46^{\mathrm{a}}$ & $16.0 \pm 1.69^{\mathrm{a}}$ & $13.7 \pm 0.63^{\mathrm{a}}$ & $12.9 \pm 0.75^{\mathrm{a}}$ & $14.9 \pm 0.95^{\mathrm{a}}$ & $14.4 \pm 1.01^{\mathrm{a}}$ & $13.0 \pm 1.01^{\mathrm{a}}$ & $14.3 \pm 0.75^{\mathrm{a}}$ & $14.8 \pm 1.58^{\mathrm{a}}$ \\
\hline
\end{tabular}

0 day parturition, (-) days pre partum, $(+)$ days post partum

a,b,c,d,e - Means within the same raw with different letters differ $(\mathrm{p}<0.05)$

Mean \pm SE 


\section{DISCUSSION}

The secretion of some hormones (glucocorticoids, thyroxin) increases during pregnancy as well, as a consequence of increased sex hormone secretion, which in turn intensifies metabolic events in the organism. Glucocorticoids improve the mobilization of extrahepatic proteins and transport of amino acids to liver cells. Mobilized amino acids in liver cells will help to synthesize glucose through gluconeogenesis, which is the primary source of energy for the embryo (Milincovic-Tur et al., 2005).

El-Sherif and Assad (2001) reported, in their study, that pregnant females had high thyroid activities. Thyroid hormones lead to amino acid mobilization from body proteins, which is associated with an increased rate of hepatic deamination (Baczynski et al., 1985; El-Sherif and Assad, 2001). In the last trimester of pregnancy, the size and the needs of fetus increase (Özpinar et al., 2004). Fetus synthesizes own all proteins from amino acids derived from mother. The survival of the fetus and placenta is dependent on important biochemical adjustments, such as the potential for anaerobic metabolism (El-Sherif and Assad, 2001). Omu and Oforofuo (1997) described, in their study, that many workers demonstrated a significant degree of anaerobic metabolism in late pregnancy and labour. Their study also demonstrated a significantly higher lactate and lactate/pyruvate ratio in late pregnancy and labour in twin pregnancy than in singleton pregnancy. LDH is associated with anaerobic degradation of glucose, a decrease in its activity indicates decreased degradation of carbohydrates (Gupta et al., 1999), and so an increase in activity indicates increased degradation of carbohydrates. Tewes et al. (1979) found that, in lactating sows, LDH activity was higher during lactation than during pregnancy. The current study indicates similarity to the results of Tewes et al. (1979). In the present study, serum CPK $(\mathrm{p}<0.05)$ and LDH $(\mathrm{p}>0.05)$ activities decreased during late pregnancy. They significantly increased at parturition $(\mathrm{p}<0.05)$. According to the studies of Baczynski et al. (1985); El-Sherif and Assad (2001); Özpinar et al. (2004), the decrease of CPK during late pregnancy is caused by fairly growth of the fetus.

Sarma and Ray (1985) stated that ALT peaked between 10 days prepartum and 10 days postpartum in goats. El-Sherif and Assad (2001) suggested that the increase in transaminases may indicate impairment in some muscle and liver cells due to rapid gluconeogenesis associated with pregnancy. Milincovic-Tur et al. (2005) reported a statistically decrease during late pregnancy and an increase during early lactation in ALT activity in Holstein mares. They recorded that plasma ALT activity was 
nearly at the same level during the entire experimental period, and by comparing, the results no significant differences could be detected (Milincovic-Tur et al., 2005). Harvey et al. (2005) reported that serum AST, ALP and GGT levels decreased during pregnancy and then significantly increased after parturition in mares. Tainturier et al. (1984) reported that, in dairy cows, the activities of AST and $\gamma$-GT showed occasional irregular, small changes during pregnancy and early lactation, while the activity of ALT significantly decreased in the $7^{\text {th }}$ and $8^{\text {th }}$ months of pregnancy and at the beginning of lactation. The activities of AST and ALT in the current study peaked on the $30^{\text {th }}$ day before parturition. Serum ALT activity showed a significant decrease only on the $10^{\text {th }}$ day of lactation period $(\mathrm{p}<0.05)$. The level of both enzymes was generally constant in the lactation period which is similar to the results of Milincovic-Tur et al. (2005) and Tainturier et al. (1984). A slight increase of AST activity in the period of early lactation may be attributed to glucocorticoid action, which gradually decreases during lactation (Milincovic-Tur et al., 2005).

Serum ALP activity is affected by stage of lactation as well as by pregnancy. In lactating dairy cows, serum ALP activity increases because of increases in bone and liver ALP activity. It peaks in early lactation and then gradually declines (Fernandez and Kidney, 2007). Tewes et al. (1979) reported that ALP activity in lactating sows was lower than the pregnancy values and did not indicate changes during the course of lactation. In the contrary, Tasker (1978) reported higher serum ALP activity in lactating mares compared with nonlactating adult horses. This result is parallel to the results obtained in the present study. Moreover, Harvey et al. (2005) suggested that the mammary gland is a potential source of this enzyme in the mare's serum. In a study of LaBorde et al. (1999), serum ALP activity increased during pregnancy in rats, decreased near parturition, and then doubled during lactation. Whereas, in the present study, serum ALP activity peaked at parturition. No significant changes in serum ALP activity were found in mares during pregnancy in previous studies by Braun et al. (1982); Meuten et al. (1980). Meuten et al. (1980) suggested that interpretation of serum ALP activity in horses can be made independently of their pregnancy status. Serum ALP concentrations in the current study significantly decreased after parturition and the values during lactation was higher than in pregnancy. The results obtained for ALP activity in this study indicate similarity to the results of Tewes et al. (1979); partly LaBorde et al. (1999).

Milincovic-Tur et al. (2005) reported that, during pregnancy and early lactation, plasma $\gamma$-GT activity in Holstein mares was nearly at the 
same level, and by comparing the results no significant differences could be detected. Harvey et al. (2005) showed that $\gamma$-GT activity in mares tended to decrease during pregnancy, and then significantly increased after parturition. Braun et al. (1982); Meuten et al. (1980) did not find significant changes in serum $\gamma$-GT activity during pregnancy in mares. Serum $\gamma$-GT activity in the present study did not indicate significant changes during the study period. This is similar to the results of Milincovic-Tur et al. (2005); Braun et al. (1982); Meuten et al. (1980). Moreover, the mean levels of $\gamma$-GT are similar to the levels determined by Tekeli et al. (1996); Amory et al. (2005).

According to the present results, activities of the measured enzymes during late pregnancy, parturition and early lactation remained within reference values recorded in different studies (Altintaş and Fidanci, 1993; Hughes et al., 2002; Mohri et al., 2005; Tekeli et al., 1996). The values obtained in this study may assist clinicians to interpret biochemical data of mares in pregnancy and lactation.

\section{REFERENCES}

Altintaş, A. and Fidanci, U.R. (1993): Evcil hayvanlarda ve insanda kanin biyokimyasal normal değerleri. Ankara Üniversitesi Veteriner Fakültesi Dergisi 40: 173-186.

Amory, H.; Perron, M.F.; Sandersen, C.; Delguste, C.; Grulke, S.; Cassart, D.; Godeau, J.M. and Detilleux, J. (2005): Prognostic value of clinical signs and blood parameter in equids suffering from hepatic disease. Journal of Equine Veterinary Sciences 25: 18-25.

Baczynski, R.; Massry, S.G.; Magott, M.; El-Belbessi, S.; Kohan, R. and Brautbar, N. (1985): Effect of parathyroid hormone on energy metabolism of skeletal muscle. Kidney International 28: 722-727.

Braun, J.P.; Bardies, J.; Thouvenot, J.P.; Benard, P. and Rico, A.G. (1982): Serum gamma-glutamyltransferase in equids: reference physiologic values. American Journal of Veterinary Research 43: 339-340.

El-Sherif, M.M.A. and Assad, F. (2001): Changes in some blood constituents of Barki ewes during pregnancy and lactation under semi arid conditions. Small Ruminant Research 40: 269-277.

Fernandez, N.J. and Kidney, B.A. (2007): Alkaline phosphatase: beyond the liver. Veterinary Clinical Pathology 36 (3): 223-233.

Gupta, A.K.; Pal, Y.; Yadav, M. and Yadav, M.P. (1999): Effect of feed deprivation on biochemical indices in equids. Journal of Equine Science 10: 33-38. 
Harris, P.A.; Marlin, D.J. and Gray, J. (1998): Plasma aspartate aminotransferase and creatine kinase activities in thoroughbred racehorses in relation to age, sex, exercise and training. Veterinary Journal 155: 295-304.

Harvey, J.W.; Pate, M.G.; Kivipelto, J. and Asquith, R.L. (2005): Clinical biochemistry of pregnant and nursing mares. Veterinary Clinical Pathology 34: 248-254.

Hughes, K.J.; Dart, J. and Hodgson, D.R. (2002): Suspected Nerium oleander (Oleander) poisoning in a horse. Australian Veterinary Journal 80: 412-415.

Johns, I.C.; Del Piero, F. and Wilkins, P.A. (2007): Hepatic encephalopathy in a pregnant mare: identification of histopathological changes in the brain of a mare and fetus. Australian Veterinary Journal 88: 337-340.

Kaneko, J.J. and Cornelius, C.E. (1971): Clinical biochemistry of domestic animals. 2nd Ed. Academic Press Inc. Ltd. New York, USA.

LaBorde, J.B.; Wall, K.S.; Bolon, B.; Kumpe, T.S.; Patton, R.; Zheng, Q.; Kodell, R. and Young, J.F. (1999): Haematology and serum chemistry parameters of the pregnant rat. Laboratory Animals 33: 275-287.

Lumej, J.T.; De Bruijne, J.J.; Slob, A.; Wolfswinkel, J. and Rothuizen, J. (1988): Enzyme activities in tissues and elimination half-lifes of homologue muscle and liver enzymes in the racing pigeon (Columbia livia domestica). Avian Pathology 17: 85-864.

Meuten, D.J.; Kociba, G.; Threlfall, W.R. and Nagode, L.A. (1980): Serum alkaline phosphatase in pregnant mares. Veterinary Clinical Pathology 9: 27-30.

Milincovic-Tur, S.; Peric, V.; Stojevic, Z.; Zdelar-Tuk, M. and Pirsljin, J. (2005): Concentrations of total protein and albumins, and AST, ALT and GGT activities in the blood plasma of mares during pregnancy and early lactation. Veterinarski Arhiv 75: 195-202.

Mohri, M.; Sardari, K. and Farzaneh, N. (2005): Serum biochemistry of Iranian Turkmen (Akhal-Teke) horses. Comparative Clinical Pathology 13: 128-131.

Oти, A.E. and Oforofuo, A.O. (1997): Comparison of the lactate-pyruvate ratio during labour and delivery in singleton and twin pregnancy. Archives of Gynecology and Obstetrics 259: 59-64.

Özpinar, A.; Şuşut, M.D. and Firat, A. (2004): Changes in selected blood serum indices before and after parturition in mares. Medycyna Weterynaryja 60: 1283-1286. 
Sarma, P.V. and Ray, T.K. (1985): Effect of physiological status on some blood enzyme levels and its relation to milk production. Indian Journal of Dairy Science 38: 237-239.

Stojevic, Z.; Pirsljin, J.; Milinkovic-Tur, S.; Zdelar-Tuk, M. and Ljubic, B.B. (2005): Activities of AST, ALT and GGT in clinically healthy dairy cows during lactation and in dry period. Veterinarski Arhiv 75: 67-73.

Tainturier, D.J.; Braun, P.; Rico, A.G. and Thouvenot, J.P. (1984): Variation in blood composition in dairy cows during pregnancy and after calving. Research in Veterinary Science 37: 129-131.

Tasker, J.B. (1978): Reference values for clinical chemistry using the Coulter Chemistry System. Cornell University College of Veterinary Medicine 68: 460-479.

Tekeli, S.K.; Örmen, A. and Mengi, A. (1996): Safkan arap ve ingiliz taylarında serum AST, ALT ve ALP aktiviteleri üzerinde çalişmalar. İstanbul Üniv. Veteriner Fakültesi Dergisi 22: 127-133.

Tewes, H.; Steinbach, J. and Smidt, D. (1979): Investigations on the blood composition of sows during the reproductive cycle III. Blood changes during lactation. Zuchthygiene 14: 159-164. 
Assiut Vet. Med. J. Vol. 56 No. 126 July 2010 
Assiut Vet. Med. J. Vol. 56 No. 126 July 2010 